\title{
Povijest umjetnosti u strateškim dokumentima razvoja turizma u Hrvatskoj: Lokalni Akcijski Plan za integrirani i održivi turizam grada Dubrovnika kao primjer dobre prakse
}

Demonja, Damir

Source / Izvornik: Institucije povijesti umjetnosti : zbornik 4. kongresa hrvatskih povjesničara umjetnosti, 2019, 283 - 292

Conference paper / Rad u zborniku

Publication status / Verzija rada: Published version / Objavljena verzija rada (izdavačev PDF)

https://doi.org/10.31664//24khpu.37

Permanent link / Trajna poveznica: https://urn.nsk.hr/urn:nbn:hr:254:202116

Rights / Prava: Attribution 4.0 International/Imenovanje 4.0 međunarodna

Download date / Datum preuzimanja: 2023-04-26

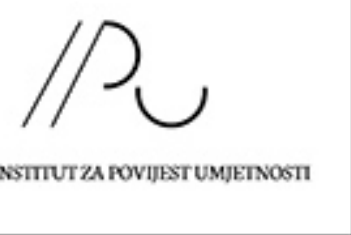

Repository / Repozitorij:

PODEST - Institute of Art History Repository

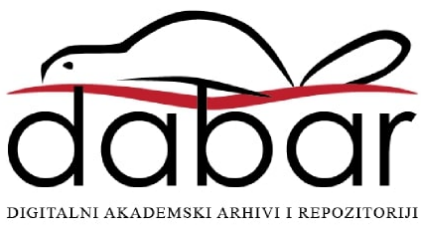




\section{Povijest umjetnosti u strateškim dokumentima razvoja turizma u Hrvatskoj: Lokalni Akcijski Plan za integrirani i održivi turizam grada Dubrounika kao primjer dobre prakse}

\section{Uvod}

Turizam bitno pridonosi cjelovitom društvenom i gospodarskom razvoju, a u hrvatskoj ekonomiji turizam ima vrlo važnu ulogu. Njegov razvoj, i rast ovisi o sustavnom razvoju i koordiniranju brojnih činitelja usmjerenih na potrošačke preferencije. Prema njima, slobodno vrijeme mora biti ispunjeno sadržajima koji obogaćuju život i u kojima dominiraju procesi, događaji i odnosi (veze).

Kada je riječ o Hrvatskoj, među dominantnim je motivima putovanja na neku od brojnih hrvatskih destinacija baština, kulturna i povijesna, koja će, nedvojbeno, dominirati i u budućnosti, nužno s obogaćivanjem, kvalitetom i dopunom same ponude. Ustaljeno je da turisti u Hrvatskoj posjećuju mjesta od povijesnog značenja, a kulturni sadržaji, više ili manje, posjećuju se u okviru gotovo svakoga turističkog putovanja. Otprije je prepoznato da je baštinu, pa tako i kulturne sadržaje, potrebno osmisliti da budu zanimljivi, poseban doživljaj, jedinstvena priča. ${ }^{1} \mathrm{U}$ tom smislu, važnu i nezamjenjivu ulogu ima povijest umjetnosti, koja mora dati vjerodostojni povijesni, umjetnički, konzervatorski i kulturološki, značenjski temelj, odnosno interpretaciju. ${ }^{2}$

Hrvatska ima posebno vrijedno kulturno-povijesno nasljeđe, a ta baština rezultat je prepletanja kulture, povijesti i civilizacije na jedinstven način u širim razmjerima. To je izniman potencijal za brojne specifične turističke proizvode i doživljaje za koje turisti pokazuju veliki interes. Upravo ti naglašeni potencijali ističu potrebu za dodatnim naporima i ulaganjem u sustavnu revitalizaciju (kulturno-povijesne) baštine i njezino ispravno prepoznavanje, jer ona bitno determinira sveukupnu turističku ponudu Hrvatske. Stoga je vrlo važno aktivno, i obvezno, uključivanje povijesti umjetnosti u izradu strateških dokumenata, poglavito strategija razvoja kulturnog turizma, ali i strategija cjelovitoga turističkog razvoja na regionalnim i lokalnim razinama, te u konzultantske i druge aktivnosti/poslove.

U ovome članku, na recentnom primjeru dobre prakse strateških

\section{Damir Demonja}

Institut za razvoj i međunarodne odnose ddemonja@irmo.hr

https://orcid.org/oooo-ooo2-4186-5²37
1 Više u: DAMIR DEMONJA, Cultural tourism in Croatia after the implementation of the Strategy of development of cultural tourism, u: International Scientific Journal-Turizam, I7(I) (20I3.), I-I7; DAMIR DEMONJA, Kulturni turizam: hrvatska iskustva, u: Antropologija, II(I) (20II.), I8I-205; DAMIR DEMONJA, Cultural Tourism in Croatia and Some European Countries: Croatian Cultural Strategies, Scientific Texts and Institutional Framework, u: Croatian International Relations Review (CIRR), I4(50/5I) (2008.), I-II; RENATA TOMLJENOVIĆ, ZRINKA MARUŠIĆ, SANDA WEBER, ZVJEZDANA HENDIJA, SNJEŽANA BORANIĆ, Croatian Cultural Tourism Policy: Strategic Development, u: Tourism, 52/4 (2004.), 36I-374; RENATA TOMLJENOVIĆ, ZRINKA MARUŠIĆ, SANDA WEBER, ZVJEZDANA HENDIJA, SNJEŽANA BORANIĆ, Strategija razvoja kulturnog turizma. Od turizma i kulture do kulturnog turizma, Zagreb, 2003.

2 Više u: DAMIR DEMONJA, Povijest umjetnosti u funkciji razvoja hrvatskog kulturnog turizma na primjeru Strategije razvoja kulturnog turizma, u: Zbornik 3. kongresa hrvatskih poujesničara umjetnosti, (ur.) Andrej Žmegač, Zagreb: Institut za povijest umjetnosti, 20I3., I25-I30; DAMIR DEMONJA, Art History in Croatian Cultural Tourism, u: Studies in Physical Culture and Tourism, I9(3), (20I2.), I2I-I27; DAMIR DEMONJA, Kulturni turizam i povijest umjetnosti: primjer Hrvatske, u: Zbornik radova s treće međunarodne naučne konferencije „Očuvanje i zaštita kulturno-istorijskog nasljeđa Srbije u inostranstvu (III)”, (ur.) Vidoje Golubović, Beograd, Institut za međunarodnu politiku i privredu, 20I2., 439-46o. 
dokumenata, pokazat će se važnost, i nužnost, aktivnog uključivanja povijesti umjetnosti koja se, na taj način, raskriva kao izrazito društveno funkcionalna. Riječ je o Lokalnom Akcijskom Planu za integrirani i održivi turizam grada Dubrounika iz 2014. godine, u okviru projekta InTourAct financirana iz fondova Europske unije. ${ }^{3}$ Glavni cilj ovoga dokumenta jest produženje turističke sezone oko urbanog područja grada Dubrovnika i smanjenje pritiska turizma na jednome mjestu, u gradu Dubrovniku. Od specifičnih ciljeva, za ovaj članak od važnosti je cilj o odgovarajućem korištenju baštine u smislu povećanja vidljivosti, atraktivnosti i dostupnosti perifernih destinacija te slijedom toga upotpunjavanja/obogaćivanja turističke ponude. U okviru tematskog područja „Kultura i baština” spomenutoga dokumenta, ključna je bila primjena povijesti umjetnost, i koja je proučila, valorizirala i predložila za aktivno korištenje baštinu, odnosno materijalne i nematerijalne kulturne resurse zadanoga područja. ${ }^{4} \mathrm{Na}$ temelju toga definiran je ključni strateški cilj, a prema njemu prioritetni/specifični ciljevi koje treba ostvariti, odnosno zadaci koje treba napraviti kako bi segment baštine analizirane u okviru ovoga dokumenta bio praktično (is)korišten.

\section{Strateški dokument Lokalni Akcijski Plan za integrirani i održivi turizam grada Dubrovnika}

Cilj i surha

Ovaj dokument rezultat je projekta InTourAct, čiji je cilj bio osigurati integrirani pristup turističkom planiranju razvoja sinergijom sektorskih politika povezanih s turizmom. ${ }^{5}$ Radi se, naime, o tome da se poveća dostupnost turističkih regija na čitavom prostoru jugoistočne Europe i poboljša turistička ponuda, čime se povećava vidljivost alternativnih turističkih destinacija i područja koja okružuju glavna središta turističke privlačnosti. Naime, turistički razvoj i upravljanje planovima na prostoru jugoistočne Europe povezan je s velikim i srednje velikim gradovima, čime se produbljuju razlike između urbanih i periurbanih/ruralnih područja, i time ograničavaju mogućnosti razvoja integriranih funkcionalnih regija jugoistočne Europe. ${ }^{6}$ S obzirom da je Dubrovnik svjetski poznato turističko odredište, izravno je povezan s ciljevima projekta InTourAct, a Lokalni Akcijski Plan predložio je razvoj ruralnih područja oko grada Dubrovnika sa svrhom rasterećenja središta Grada, u ovom primjeru stare gradske jezgre, što pridonosi učinkovitom upravljanju održivim turizmom.

Stalno godišnje povećanje broja dolazaka turista u Dubrovnik stvorilo je potrebu za Lokalnim Akcijskim Planom, koji bi, na stanovit način, pridonio rješavanju preusmjeravanja određenog broja turista u periurbana i ruralna područja, time doprinio razvoju tih područja i učinio razvoj turizma mogućim u odveć posjećenu Dubrovniku. S ovim Lokalnim Akcijskim Planom grad Dubrovnik je, kao hrvatski partner, sudjelovao u projektu InTourAct, i uključio je razvoj ruralnog turizma i integraciju turističke ponude ovih područja: održivi turizam-Grad Dubrovnik, Institut za razvoj i međunarodne odnose, IRMO, Zagreb, 20I4., 5I.

4 InTourAct-Lokalni Akcijski Plan za integrirani i održivi turizam-Grad Dubrovnik (bilj. 3), 22-25.
5 Projekt InTourAct provodio se u partnerstvu iI općinskih, lokalnih i regionalnih vlasti iz Italije, Mađarske, Slovenije, Grčke, Bugarske, Hrvatske i Bosne i Hercegovine, a na čelu je Provincija Rimini. U Hrvatskoj je realiziran u suradnji Razvojne agencije grada Dubrovnika, DURA-e, iz Dubrovnika, brojnih lokalnih dionika i Instituta za razvoj i međunarodne odnose, IRMO, iz Zagreba.

6 Više o važnosti integriranog turizma u: TOVE OLIVER, TIM JENKINS, Sustaining Rural Landscape: The Role of Integrated Tourism, u: Landscape Research, 28(3) (2003.), 293-307. 
- Gornja sela: Gromača, Ljubač, Mrčevo, Kliševo, Mravinjac i Riđica

- Donja sela: Osojnik,Zaton, Orašac, Trsteno i Brsečine Dubravica

- Elafiti: Koločep, Lopud i Šipan (Suđurađ)

- Bosanka i ruralno područje Rijeke dubrovačke (Rožat, Komolac, Mokošica)

- ostala sela u ruralnom području Rijeke Dubrovačke: Prijevor, Knežica, Sustjepan, Dračevo Selo, Petrovo Selo, Čajkovići i Čajkovica

Vizija integriranog i održivog razvoja turizma u gradu Dubrouniku

Područje grada Dubrovnika izvrstan je primjer povijesno-urbanog (povijesna jezgra Dubrovnika) i ruralnog područja (dubrovačka Gornja sela, Donja sela, Elafitsko otočje, Trsteno i druga naselja), te arhitektonske baštine koja je okvir za kreiranje kultiviranog, funkcionalnog prostora, poštujući koncept genius loci, odnosno duha mjesta.

Grad Dubrovnik značajan je činitelj svjetske kulturne baštine kao jedinstvena urbanistička cjelina nastala tijekom razdoblja srednjega vijeka, renesanse, baroka i moderne, čija je vrijednost okrunjena i UNESCO-ovom zaštitom I979. godine kao unikatne i neponovljive svjetske baštine. Dubrovnik je danas jedna od najprepoznatljivijih atrakcija Mediterana, koja godišnje privlači velik broj posjetitelja, stacionarnih (gosti koji borave u Dubrovniku) kao i izletnika (gosti s kruzera). Dubrovnik se određuje kao povijesno središte luksuznog turizma jugoistočne Europe koje se izdvaja po kvaliteti ponude hotelske industrije, događanjima vezanima za kulturu i profilu gostiju koji ga posjećuju.

Osim povijesne, urbane cjeline grada, Dubrovnik obuhvaća i teritorij koji mu prirodno gravitira: Elafitsko otočje (vrlo atraktivno područje s brojnim crkvicama, kapelicama i vlastelinskim ljetnikovcima iz razdoblja Dubrovačke Republike te atraktivnim pješčanim plažama i prekrasnim krajolicima), Rijeku dubrovačku (velik broj vlastelinskih ljetnikovaca iz vremena Dubrovačke Republike), dubrovačka Gornja i Donja sela (ruralna područja grada) s bogatom kulturnom baštinom: folklor, običaji, pučke predaje, pučke i vjerske manifestacije, ruralna arhitektura, očuvani tradicijski zanati, tradicijska, ekološka poljoprivredna i stočarska proizvodnja, kao i ona tipičnih proizvoda (vino, maslinovo ulje, sir, suhomesnati proizvodi).

Duh mjesta u gradu Dubrovniku s vremenom se mijenjao, a svrha njegova razumijevanja uključuje i ideju o budućem pažljivom planiranju, upravljanju i usmjeravanju grada integriranom održivom razvoju. Integriranim pristupom moguće je poticati održivi razvoj ruralnog turizma i komplementarnih djelatnosti (ekološka poljoprivreda, proizvodnja tipičnih lokalnih proizvoda), kreirajući jedinstven, konkurentan, inovativan i kompleksan turistički proizvod i destinaciju uključivanjem ruralnog područja grada Dubrovnika u turističku ponudu destinacije. ${ }^{7}$

7 World Tourism Organization Network. Sustainable Development of Tourism. URL: http://sdt.unwto.org/ content/about-us-5 (posjećeno 2. prosinca 20I6.). 
Vizija daljeg razvoja turizma u Dubrovniku temelji se na integraciji same zaštićene urbane cjeline grada kao najveće atrakcije u Hrvatskoj i jedne od važnijih na cijelom Mediteranu, sa svim područjima koja gravitiraju Dubrovniku: Elafitskim otočjem, dubrovačkim Gornjim i Donjim selima te Rijekom dubrovačkom u jedinstveni turistički proizvod satkan od niza kulturoloških i ambijentalnih specifičnosti, a ponajprije od očuvana i čista prirodnog okoliša, odnosno atraktivne i vrlo vrijedne prirodne okoline, organiziranih i ponuđenih kao turističke atrakcije. Razvoj integriranog turizma na području grada Dubrovnika treba se temeljiti isključivo na principima održivog razvoja i odgovornom iskorištavanju resursne osnove. ${ }^{8}$ Predloženu viziju moguće je ostvariti isključivo ako se potakne međusobna suradnja svih zainteresiranih skupina (institucija, poduzetnika i nevladina sektora) u području turizma, ruralnog turizma, kulturnog turizma, ugostitelja i ostalih pružatelja usluga ruralnog područja oko grada Dubrovnika kroz destinacijsko poduzetništvo, potom ako se pojača vidljivost destinacije ruralnog područja oko grada Dubrovnika na turističkim tržištima i osmisli integralni turistički proizvod temeljen na iskustvenim doživljajima. ${ }^{9}$

Pritom su preduvjeti za razvoj ruralnog turizma oko grada Dubrovnika izgradnja komunalne infrastrukture u ruralnim područjima, podizanje kvalitete smještajnih kapaciteta i ostalih turističkih usluga na ruralnim područjima oko Dubrovnika te samozapošljavanje i zapošljavanje educiranih i stručnih kadrova za opsluživanje modernih turističkih usluga. ${ }^{10}$

Kultura i baština kao jedna od strateških tema Lokalnog Akcijskog Plana za integrirani i održivi turizam grada Dubrounika

U okviru Lokalnog Akcijskog Plana za integrirani i održivi turizam grada Dubrounika, ${ }^{11}$ tematsko područje „Kultura i baština” usredotočeno je na detektiranje i primjenu relevantnih sastavnica baštine u svrhu razvoja te potom i promicanje novih turističkih područja. Cilj je uspostaviti i osnažiti važnost kulture i nasljeđa u smislu afirmacije kulturnog identiteta područja oko grada Dubrovnika u kontekstu suvremenoga turističkog razvoja koji se temelji na kulturi i baštini te trendovima u kulturi i novim načinima korištenja baštine. U okviru te teme proučavani su kultura i baština, odnosno materijalni i nematerijalni kulturni resursi zadanog područja.

Ruralna područja, koja su predmet Lokalnog Akcijskog Plana, također obiluju vrijednom kulturnom baštinom, neka od njih nisu dovoljno istražena i/ili valorizirana, no izdvojena je ona baština, na svakom od proučavanih područja, koja predstavlja važnu resursnu osnovu za kvalitetni razvoj ruralnoga turizma na tome području.

Osim materijalne kulturne baštine od važnosti je i ona nematerijalna. U nju se ubrajaju tradicionalne manifestacije, festivali, vjerska događanja, raznovrsne priredbe i drugo, koji imaju lokalnu i županijsku važnost, te tako čine potencijalno važne
8 Strategija razvoja grada Dubrovnika do 2020. godine, Dubrovnik, 2007:; Generalni urbanistički plan grada Dubrovnika, Dubrovnik, 2005. (izmjene 2007., 2012. i 20I4. godine).

9 Strategija razvoja turizma Dubrovačko-neretvanske županije za razdoblje 20I2.-2022. godine, Zagreb, 2013.

Io Plan prostornog uređenja grada Dubrovnika, Zagreb, 2013.; Strategija razvoja ljudskih potencijala Dubrovačko-neretvanske županije 20II.-20I3 godine, Dubrovnik, 20II.

II Lokalni Akcijski Plan za integrirani i održivi turizam grada Dubrounika temeljni je dokument kojim se, polazeći od analize stanja u gradu Dubrovniku i gradskim ruralnim područjima, te temeljem swoTanalize (identifikacije ključnih snaga i slabosti te mogućnosti i prepreka), definiraju temeljne strateške odrednice i prioriteti organiziranja održivih turističkih aktivnosti u gradu Dubrovniku i njegovim ruralnim područjima ciljanim aktivnostima kroz četiri definirana tematska područja: ı. Okoliš, 2. Mobilnost, 3. Kultura i baština, i 4. Inovacije i profesionalne vještine. 
(kulturno) turističke proizvode, a nekima od njih vrijednost je veća i važnija jer se događaju izvan glavne turističke sezone.

$\mathrm{Na}$ temelju raspoložive kulture i baštine ruralno područje grada Dubrovnika ima potencijala za konkurentsku prednost u unificiranoj i globaliziranoj turističkoj ponudi. Uključivanje kulture i baštine ima pozitivan gospodarski i društveni učinak, gradi i naglašava identitet, pomaže u očuvanju kulturne baštine, pruža potporu kulturi i pomaže obnovu turizma.

Kulturno-povijesno nasljeđe predmetnog (proučavanog) područja (prostora) obuhvaćeno ovim Lokalnim Akcijskim Planom veliki je turistički potencijal i vrijednost za razvoj turizma. Veći broj elemenata kulturne baštine spomenutog područja sistematiziran je prema Registru kulturnih dobara Republike Hrvatske, ${ }^{12}$ a određeni je broj evidentiran. Kulturna baština područja oko grada Dubrovnika obuhvaća:

- Kulturno-povijesne spomenike:

- arheološka nalazišta

- spomeničke cjeline

- memorijalna područja i građevine

- urbane cjeline

- pojedinačne sakralne građevine (crkve)

- pojedinačne profane zgrade i građevine (vile, hoteli, i drugo)

- Kulturu života i rada (folklor)

- Manifestacije (kulturne, vjerske i popularno-zabavne)

- Kulturne i vjerske ustanove (muzeji)

Tablica I

Kulturna baština područja oko grada Dubrovnika

Izvor: Registar kulturnih dobara Republike

Hrvatske, Zagreb, 20I6., i istraživanja autora
I2 Registar kulturnih dobara Republike Hrvatske, Ministarstvo kulture Republike Hrvatske, Zagreb, 20I6. URL: http://www.min-kulture.hr/default. aspx?id=3I (posjećeno 2 . prosinca 2016.).

\begin{tabular}{|c|c|c|c|c|c|c|}
\hline \multirow[t]{2}{*}{ Područje } & \multicolumn{6}{|c|}{ Kulturno-povijesni spomenici } \\
\hline & $\begin{array}{l}\text { Arheološka } \\
\text { nalazišta }\end{array}$ & $\begin{array}{l}\text { Spomeničke } \\
\text { cjeline }\end{array}$ & $\begin{array}{l}\text { Memorijalna } \\
\text { područja i } \\
\text { gradevine }\end{array}$ & $\begin{array}{l}\text { Urbane/ ruralne } \\
\text { cjeline }\end{array}$ & $\begin{array}{l}\text { Pojedinačne } \\
\text { sakralne } \\
\text { gradevine (crkve) }\end{array}$ & $\begin{array}{l}\text { Pojedinačne } \\
\text { profane zgrade } \\
\text { i građevine (vile, } \\
\text { hoteli i drugo) }\end{array}$ \\
\hline Gromača & - & - & - & - & - & - \\
\hline Ljubač & - & - & - & - & - & - \\
\hline Mrčevo & $\begin{array}{l}\text { Crkva sv. Šimuna } \\
\text { Jude sa stećcima, } \\
\text { Kručica, Gomila, } \\
\text { Slivje }\end{array}$ & - & - & - & - & - \\
\hline Kliševo & - & - & - & - & Crkva sv. Mihovila & - \\
\hline Mravinjac & $\begin{array}{l}\text { Gomila, Osoje, } \\
\text { Dugaje, Ivanova } \\
\text { glavica }\end{array}$ & - & - & - & - & - \\
\hline Riđica & - & - & - & - & - & - \\
\hline Osojnik & - & - & - & - & - & - \\
\hline Zaton & - & $\begin{array}{l}\text { Ljetnikovci } \\
\text { obitelji Gučetić, } \\
\text { Menčetić, } \\
\text { Sorkočević, } \\
\text { Saraka i } \\
\text { Lukačević }\end{array}$ & - & - & - & - \\
\hline
\end{tabular}




\begin{tabular}{|c|c|c|c|c|c|c|}
\hline Područje & \multicolumn{6}{|c|}{ Kulturno-povijesni spomenici } \\
\hline Orašac & - & $\begin{array}{l}\text { Dvorac Arapovo } \\
\text { (Soderini) }\end{array}$ & - & - & $\begin{array}{l}\text { Župna crkva } \\
\text { Gospe od Orašca } \\
\text { sa slikama } \\
\text { sv. Marije i sv. } \\
\text { Ivana Krstitelja } \\
\text { (registrirane na } \\
\text { listi zaštićenih } \\
\text { dobara } \\
\text { Ministarstva } \\
\text { kulture RH) }\end{array}$ & - \\
\hline Trsteno & $\begin{array}{l}\text { Arheološki nalazi } \\
\text { i stećci }\end{array}$ & $\begin{array}{l}\text { Ljetnikovac } \\
\text { Gučetić-Gozza }\end{array}$ & - & - & - & - \\
\hline Koločep & - & Tvrđava Kaštio & - & - & $\begin{array}{l}\text { Crkva Blažene } \\
\text { Gospe, crkva sv. } \\
\text { Antuna Opata } \\
\text { (Kaštio), crkva } \\
\text { sv. Trojstva } \\
\text { (zaselak Mačus), } \\
\text { crkva sv. Antuna } \\
\text { Padovanskog } \\
\text { (Gornje čelo), } \\
\text { crkva sv. Nikole na } \\
\text { groblju }\end{array}$ & Stambene cjeline \\
\hline Bosanka & $\begin{array}{l}\text { Arheološki } \\
\text { lokaliteti Bosanka: } \\
\text { crkva sv. Srđa, } \\
\text { Gradac, Mali } \\
\text { Gradac, Gomila } \\
\text { i Gomila više } \\
\text { Dalića }\end{array}$ & $\begin{array}{l}\text { Fortifikacijski } \\
\text { krajolik Bosanka: } \\
\text { tvrđava Imperial, } \\
\text { Streljački poligon } \\
\text { (Streljana), utvrda } \\
\text { Delgorgue na } \\
\text { Žarkovici i utvrda } \\
\text { Strinčjera }\end{array}$ & - & $\begin{array}{l}\text { Ruralna cjelina } \\
\text { Bosanka: crkva sv. } \\
\text { Spasa, kompleks } \\
\text { Ruskovina, kuća } \\
\text { Milosavić, kuća } \\
\text { Pulitika, kuća } \\
\text { Paskojević i Križ } \\
\text { na Srđu, plato Srđ }\end{array}$ & - & - \\
\hline Rožat & - & Ljetnikovac Rastić & - & - & $\begin{array}{l}\text { Franjevački } \\
\text { samostan s } \\
\text { klaustrom } \\
\text { i crkvom } \\
\text { Pohođenja } \\
\text { Blažene Djevice } \\
\text { Marije }\end{array}$ & - \\
\hline Komolac & - & - & - & - & Crkva sv. Duha & - \\
\hline Mokošica & - & - & - & - & - & - \\
\hline
\end{tabular}


Veći broj različitih kategorija kulturno-povijesnog nasljeđa nije, ili je samo djelomično, prilagođen za turističke posjete, odnosno za uporabu u turističke svrhe, kao svojevrsni (kulturno) turistički proizvod, što je izraziti nedostatak u organizaciji integrirane, cjelovite turističke ponude proučavanoga područja. U tablici I izdvojeni su pojedinačni primjeri kulturne baštine kao potencijali za uključivanje u turističku ponudu.

Nematerijalna baština na području ruralnih naselja grada Dubrovnika obuhvaća 39 manifestacija/događanja, od kojih se njih sedam više-manje temelji na tradicionalnoj kulturi. Od manifestacija/događanja najveći je broj koncerata klasične glazbe, potom onih u izvedbi lokalnih glazbenika (limena glazba) i nacionalnih izvođača/pjevača te prigodnih turističkih, uglavnom ljetnih zabavnih događanja (tzv. noći). Manifestacije/događanja koje se temelje na tradicionalnoj lokalnoj kulturi jesu slavljenja Velike Gospe (proslave na otocima Koločepu i Lopudu), lokalnih svetaca/ svetica zaštitnika mjesta/naselja (Sv. Stjepan, Šipan i Zaton; Gospa od Orašca, Orašac; Gospa od Karmena, Suđurađ na Šipanu), Uskrsa (manifestacija Uskrs u Primorju u Mrčevu i Ljubaču-Gornjim selima, koja je jedina izvorna tradicionalna manifestacija) i festivalima folklora (Osojnik). U čuvanju i promicanju nematerijalne kulturne baštine osobito su aktivne udruge i kulturno-umjetnička društva, a kao dobri primjeri ističu se Dubrovački primorski suatovi, o kojima se brine istoimena udruga i Priče iz salačkih komina u organizaciji KUD-a Sv. Juraj iz Osojnika.

Slijedom navedenoga može se zaključiti da je kulturna i baštinska resursna osnova za razvoj ruralnog turizma proučavanih područja bogata, raznolika, vrijedna i rasprostranjena, ali nije u dovoljnoj mjeri valorizirana, nisu izdvojeni njezini razvojni potencijali $i$, zapravo, nije u cijelosti ni inventarizirana, odnosno ne postoji odgovarajući registar resursa, mogućnosti i uvjeta njezina održivog korištenja. Zamjetan je nedostatak istraživanja, praćenja i vrednovanja kulturne baštine te njezina prezentiranja. Kako bi baština i nasljeđe dobili odgovarajuću ulogu u razvoju ruralnih područja oko grada Dubrovnika, potrebno je ponovno učiniti njihovu inventarizaciju, a potom i valorizaciju, na temelju kojih će biti moguće osmisliti, odnosno predložiti, načine njihova očuvanja, održivog korištenja i upravljanja. 
Dubrounika

swoT-analiza predstavlja identifikaciju ključnih snaga i slabosti te mogućnosti i prepreka, a swOT-analiza kulture i nasljeđa područja oko grada Dubrovnika pokazala je stanje kao u tablici 2.

Tablica 2

sWOT-analiza kulture i nasljeđa područja oko grada Dubrovnika Izvor: istraživanje autora

\begin{tabular}{|c|c|}
\hline Snage & Slabosti \\
\hline $\begin{array}{l}\text { - bogata i raznovrsna, kulturna i baštinska, materijalna i } \\
\text { nematerijalna osnova } \\
\text { - velik broj evidentiranih, preventivno zaštićenih i } \\
\text { registriranih spomenika kulture } \\
\text { - očuvani kulturni običaji, tradicija, povijest i vrijednosti } \\
\text { lokalne zajednice }\end{array}$ & $\begin{array}{l}\text { - nedovoljno istražena, valorizirana i prezentirana } \\
\text { kulturna baština } \\
\text { - nedovoljna briga i zaštita baštine s obzirom na njezinu } \\
\text { brojnost i raznovrsnost } \\
\text { - neprimjerena zastupljenost baštine ruralnih područja u } \\
\text { turističkoj ponudi grada Dubrovnika } \\
\text { - nedovoljno korištenje kulture kao razvojnog resursa } \\
\text { prema načelima održivog razvoja (npr. kulturno } \\
\text { poduzetništvo, kulturne industrije, prostorno uređenje, } \\
\text { teritorijalna regeneracija/revitalizacija...) }\end{array}$ \\
\hline Prilike & Opasnosti \\
\hline $\begin{array}{l}\text { - mogućnosti reaktivacije baštine, građevina/objekata, } \\
\text { arhitektonskih/spomeničkih cjelina od strane države i/ } \\
\text { ili pojedinaca u turističke svrhe } \\
\text { - mogućnosti korištenja programa i fondova EU za } \\
\text { financiranje zaštite, obnove i stavljanje kulturne baštine } \\
\text { u turističke svrhe } \\
\text { - jačanje uloge civilnog društva u zaštiti, revitalizaciji i } \\
\text { korištenju kulturne baštine } \\
\text { - provedba strategija razvoja kulturnog i ruralnog turizma, } \\
\text { nacionalnih i lokalnih (županijskih) }\end{array}$ & $\begin{array}{l}\text { - nepostojanje čvrstih i konkretnih odluka lokalne } \\
\text { samouprave o zaštiti kulturnih krajolika } \\
\text { - nepostojanje standarda gradnje novih objekata u } \\
\text { ruralnim područjima } \\
\text { - prirodne nepogode (zona potresa) } \\
\text { - neprihvatljive investicije u kulturnu baštinu -izostanak } \\
\text { i/ili neodgovarajuća provedba kvalitetne zaštite, obnove } \\
\text { i održavanja kulturne baštine } \\
\text { - uništavanje kulturne baštine }\end{array}$ \\
\hline
\end{tabular}

\section{Zaključak: Strateški cilj, prioriteti ili specifični ciljevi te programi ili aktivnosti u tematskom području „Kultura i baština"}

$\mathrm{Na}$ temelju opisa stanja i swOT-analize strateškog područja „Kultura i baština” kao strateški cilj definirano je: očuvanje i održivo korištenje kulturne baštine ruralnih dijelova grada Dubrovnika za potrebe turizma.

Prioriteti ili specifični ciljevi koji doprinose ostvarenju strateškoga cilja jesu:

- revizija kulturne baštine, posebno spomenika kulturno-povijesne baštine, kako bi se mogli primjereno zaštititi od dalje devastacije

- održavanje i obnavljanje spomenika kulturno-povijesne baštine

- valorizacija tradicijskih lokalnih resursa u cilju razvoja ruralnog turizma na područjima oko grada Dubrovnika

- integracija obiteljskih seoskih gospodarstava i razvoj zajedničke prepoznatljive turističke ponude temeljene na zajedničkoj kulturnoj (i prirodnoj) baštini

- poticanje i promicanje projekata održivog turizma (kulturnog i ruralnog) 
- unapređenje programa korištenja kulturne baštine u ruralnom turizmu (obnova tradicijske arhitekture, oživljavanje starih zanata, očuvanje folklora i etnobaštine, promicanje znanja o tradicijskim vrijednostima, prezentacija kulturno-povijesne baštine, itd.)

- zadržavanje, privlačenje i kontinuirano usavršavanje ljudskih potencijala, odnosno stručnih kadrova čija je zadaća podizanje svijesti o kulturi i baštini te njezinu očuvanju, u suradnji s Gradom Dubrovnikom

- očuvanje, zaštita i održivo korištenje kulturne baštine i lokalnih vrijednosti u funkciji razvoja ruralnog turizma, turizma općenito, i na taj način poticanje razvoja lokalne zajednice

- podizanje svijesti lokalnog stanovništva o vrijednosti i značenju kulturne baštine u smislu očuvanja i razvoja identiteta obrađivanog područja, te njegovog napretka u cjelini

- kontinuirano informiranje, educiranje i motiviranje lokalnog stanovništva o vrijednostima i značenju kulturne baštine

Te prioritete ili specifične ciljeve moguće je ostvariti pripremom i provedbom ovih programa:

- Program revitalizacije autohtonih ruralnih kuća: izrada posebnog programa očuvanja s detaljno definiranim smjernicama zaštite i revitalizacije autohtonih ruralnih kuća za potrebe turizma. Cilj je definirati i model financiranja kao i način izvođenja.

- Program očuvanja baštine (mlinice, stari zanati, etnozbirke, nematerijalna baština) u funkciji ruralnog turizma: izrada posebnog programa očuvanja materijalne i nematerijalne baštine $u$ funkciji ruralnog turizma. Cilj programa je, istodobno s očuvanjem i zaštitom, artikulirati i predstaviti baštinu kao turistički proizvod u smislu kvalitetne nadopune usluga $\mathrm{u}$ ruralnom turizmu te prezentirati kulturno nasljeđe i tradicionalnu kulturu življenja na ruralnim područjima grada Dubrovnika.

- Program obnove i revitalizacije kulturne baštine u privatnom vlasništvu (potpore i učinkoviti financijski aranžmani) kroz mogućnost kondominija (zajedničko osmišljavanje aktivnosti i zajedničko upravljanje proizvodom putem marketinga i prodaje) nad objektima kulturne baštine od strane izabrane upravljačke strukture integriranog i održivog turizma grada Dubrovnika, a ti objekti imali bi turističku funkciju.

U provedbi navedenih programa očekuje se aktivno uključivanje svih relevantnih dionika-građana, pojedinaca uključenih $u$ kulturu i očuvanje kulturne baštine, organizacija civilnog društva, strukovnih organizacija te tijela i organizacija lokalne samouprave. Očekivani rezultati tih aktivnosti bili bi poboljšana briga, zaštita i očuvanje kulturne baštine, povećani broj obnovljenih građevina/objekata kulturne baštine te povećani broj i vrsta različitih manifestacija kulturne baštine, posebno onih u vezi s tradicijom i identitetom lokalnih zajednica, potom povećana briga i sudjelovanje lokalnog stanovništva u očuvanju kulturne baštine, kreiranje novih (kulturno)turističkih proizvoda, otvaranje novih radnih mjesta te povećanje broja i strukture posjetitelja na proučavanom području.

Neposredni doprinos u svemu navedenom imala je upravo povijest umjetnosti, koja se pokazala kao ključna disciplina u kreiranju 
strateškog dokumenta koji u sebi uključuje održivi i strateški oblik razvoja te višedimenzionalno i integrativno planiranje. Povijest umjetnosti aktivno je sudjelovala u definiranju temeljnih strateških odrednica i prioriteta organiziranja održivih turističkih aktivnosti u gradu Dubrovniku i njegovim ruralnim područjima ciljanim aktivnostima u tematskom području „Kultura i baština”. Na taj način povijest umjetnosti pokazala je da je povezana s mjestima koja su obrađivana i da je nužna za povezivanje i aktivaciju lokalnih resursa i aktivnosti s participativnom lokalnom zajednicom. Ona je, tako, aktivni posrednik potrebe za društveno-gospodarskom preobrazbom proučavanoga područja u smislu aktivna utjecaja na njegov gospodarski i prostorni razvoj te oblikovanje boljeg društvenog života i kulturne infrastrukture. Time je povijest umjetnosti nadišla svoje pretežno akademsko obilježje, odnosno karakter, i pokazala se kao potrebna i opravdana društvena inicijativa.

\section{(c) (i)}

Povijest umjetnosti u strateškim dokumentima razvoja turizma u Hrvatskoj: Lokalni Akcijski Plan za integrirani i održivi turizam grada Dubrounika kao primjer dobre prakse / Damir Demonja/CC BY / 4.0

DoI: https://doi.org/Io.3I664/z4khpu.37 